\title{
BUDIDAYA IKAN LELE DUMBO INTENSIF SISTEM AKUAPONIK UNTUK PEMBERDAYAAN PANTI ASUHAN MUHAMMADIYAH DI KECAMATAN KENJERAN KOTA SURABAYA
}

\section{CULTIVATION OF DUMBO CATFISH INTENSIVE IAPONIC SYSTEM FOR EMPOWERMENT OF MUHAMMADIYAH ORPHANAGE IN KENJERAN SUB-DISTRICT OF SURABAYA CITY}

\author{
Prayogo \\ Perairan Fakultas Perikanan dan Kelautan. Jl. Dharmahusada Permai No. 330, Mulyorejo, Kota SBY, Jawa Timur 60115. \\ Kampus C Unair - Surabaya
}

\section{Purwanto}

Fakultas Perikanan dan Kelautan. Jl. Dharmahusada Permai No. 330, Mulyorejo, Kota SBY, Jawa Timur 60115. Kampus C Unair - Surabaya

\section{Rahardja}

Fakultas Perikanan dan Kelautan. Jl. Dharmahusada Permai No. 330, Mulyorejo, Kota SBY, Jawa Timur 60115. Kampus C Unair - Surabaya

\begin{abstract}
Abstrak
Surabaya adalah salah satu wilayah Jawa Timur dengan tingkat konsumsi ikan cukup tinggi. Dalam kegiatan usaha produksi ikan konsumsi di kota Surabaya, salah satu spesies ikan yang memungkinkan untuk dikembangkan melalui kegiatan budidaya adalah ikan lele. Sebab ikan lele memiliki keunggulan dari ikan-ikan lain karena termasuk ikan yang memiliki daya tahan kuat dan dapat dipelihara dengan padat tebar tinggi. Kegiatan budidaya lele dumbo akan semakin marak apabila dikembangkan di wilayah pesisir Kota Surabaya mengingat banyaknya potensi bahan pakan murah berupa limbah ikan tanggkapan yang kurang dimanfaatkan oleh masyarakat pesisir. Hanya saja saat ini lahan dan sumber air masyarakat pesisir kota Surabaya umumnya terbatas, sehingga perlu diperkenalkan suatu model budidaya ikan lele dumbo dengan pemanfaatan lahan dan sumber air yang terbatas. Mengatasi masalah tersebut, diperlukan sistem teknologi budidaya ikan yang tepat untuk diterapkan pada kegiatan usaha budidaya ikan lele dumbo di kota Surabaya dan teknologi tersebut adalah budidaya ikan lele dumbo dengan intensif sistem akuaponik.
\end{abstract}

Kata kunci: budidaya lele, aquaponik

\begin{abstract}
Surabaya is one of the East Java region with relatively high levels of fish consumption. In a food fish production activity in Surabaya, one of the species of fish which allows for developed through cultivation is catfish. Since catfish has the advantage than other fish because it has good durability and can be cultivated in high density. African catfish cultivation activity will be increase if it is developed in coastal region of Surabaya because there is many potential of fish catches waste as feed which are underutilized by coastal communities. Only this time the land and water resources of coastal area in Surabay a are generally limited, so it is necessary to know a model of African catfish fish farming with the use of limited land and water resources. For overcoming these problems, it is needed system of fis harming technology appropriate to be applied to the activities of African catfish farming in Surabaya and the technology is the dumbo catfish cultivation with intensive system akuaponic.
\end{abstract}

Keywords: catfish farming, aquaponic

\section{PENDAHULUAN}

Panti asuhan merupakan suatu lembaga pendidikan untuk membentuk perkembangan anak anak yang tidak memiliki keluarga atau tidak tinggal bersama keluarganya, dimana menurut (Depsos RI, 2004) panti asuhan mempunyai tanggung jawab untuk memberikan pelayanan kesejahteraan sosial dan mental. Undang-Undang Republik Indonesia No.4 Tahun 1979 pasal 2 ayat 1. menjelaskan bahwa setiap anak berhak mendapat kesejahteraan, perawatan, asuhan, bimbingan (pendidikan). Pada kenyataanya masih banyak 
panti asuhan yang terkendala terkait biaya operasional dalam melakukan pengembangan pembinaan anak anak panti, hal ini disebabkan oleh banyak hal salah satu diantaranya adalah sedikit panti asuhan yang mempunyai sumber penghasilan sendiri (mandiri). Adapun potensi yang dimiliki sebagian besar panti asuhan adalah SDM yang bisa diberdayakan untuk menjawab permasalahan tersebut, salah satu usaha adalah kegiatan usaha budidaya ikan lele dumbo.

Budidaya lele adalah solusi alternatif dalam menunjang kemandirian panti asuhan, selain cara budiaya yang relatif mudah, kebutuhan akan lele secara signifikan terus meningkat dari 22,5 kg per kapita setiap tahunnya pada tahun 2004 menjadi 28,28 kg/kapita/th pada tahun 2008 (Data BPS, 2009). Selain itu kebutuhan protein (gizi) yang tinggi belum cukup terpenuhi, hal ini dikarenakan harga ikan relatif mahal dan jumlah stok yang kurang.

Panti Asuhan Muhammadiah Kec. Kenjeran merupakan panti asuhan yang telah memiliki usaha budidaya ikan lele dumbo. Panti asuhan tersebut memiliki potensi terkait luas lahan pekarangan yang bias dioptimalkan untuk pembuatan kolam terpal. Terkait dengan potensi pasar sangat bagus sebab Kota Surabaya merupakan salah satu pasar terbesar ikan lele di Jawa Timur.

Berbagai teknis budidaya lele yang telah dikembangkan untuk mendapatkan hasil panen yang memuaskan, satu adalah budidaya sistem akuaponik. Sistem budidaya ini dapat dipadukan dengan pemeliharaan tanaman. Budidaya sistem akuaponik mempunyai prinsip memanfaatkan air secara terus menerus dari pemeliharaan ikan ke tanaman dan sebaliknya dari tanaman ke kolam ikan. Sistem ini menyebabkan kondisi perairan budidaya selalu dalam kondisi optimal, sehingga komoditi yang dibudidayakan dapat tumbuh dan berkembang secara maksimal.

Oleh karena itu perlu dikembangkan budidaya lele intensif dengan sistem akuaponik ini dan perlu dilakukan pelatihan ketrampilan kegiatan usaha budidaya bagi pengurus panti asuhan dengan harapan budidaya lele intensif ini mampu menjadi bekal kemandirian dari panti panti yang ada di kota Surabaya.

\section{METODE PELAKSANAAN}

Dalam pelaksanaan kegiatan pengabdian Pengmas ini, tim pelaksana merencanakan kegiatan selama 1 tahun dalam upaya pencapaian tujuan program. Perencanan kegiatan dibagi menjadi 6 tahap. Tahapan kegiatan adalah sebagai berikut:

\section{Tahap I}

Pengenalan model budidaya lele dumbo sistem akuaponik di Panti Asuhan Muhammadiah Kecamatan Kenjeran kota
Surabaya, hal ini dimaksudkan supaya mendapatkan wawasan dan pemahaman yang benar terkait sistem budidaya dengan maksud didapatkan produksi yang optimal dan berkelanjutan. Pelatihan tentang manajemen benih ikan yang baik dan penyiapan air pra/post budidaya, managemen pemberian pakan, greeding ikan, serta manajemen panen yang benar serta proses pemasaran.

\section{Tahap II}

Pendampingan pembuatan konstruksi kolam dengan budidaya lele dumbo sistem akuaponik, dimulai dari penyiapan lokasi untuk kolam, kebutuhan alat dan bahan sampai dengan cara perawatan kolam sebelum penebaran benih ikan lele. Pendampingan model budidaya lele dumbo sistem akuaponik pada setiap panti asuhan, serta pembagian tugas setiap individu terkait pelaksanaan budidaya.

\section{Tahap III}

Analisa usaha sistem budidaya yang meliputi analisa produksi (pertumbuhan, mortalitas, size panen) dan analisa usaha (cost produksi dan income). Evaluasi dan monitoring dari model budidaya lele dumbo sistem akuaponik yang telah berlangsung (post budidaya) dengan harapan didapatkan solusi alternatif dalam meningkatkan produksi, sehingga kegiatan produksi budidaya dapat berlangsung secara mandiri dan kontinyu.

\section{HASIL DAN PEMBAHASAN}

Tujuan yang ingin dicapai dalam kegiatan ini adalah agar nantinya hasil produksi pembesaran ikan lele dumbo semakin meningkat. Metode pendekatan yang akan dilakukan dalam Program Pengmas ini adalah memberikan wawasan, ilmu pengetahuan dan teknologi tepat guna yang sederhana dan mudah untuk diaplikasikan serta dikembangkan kepada para pembudidaya ikan lele dumbo di Surabaya. Teknologi yang ingin ditawarkan budidaya sistem akuaponik ini adalah teknologi tepat guna yang mempunyai prinsip pemanfaatan air dari pemeliharaan ikan ke tanaman dan sebaliknya dari tanaman ke kolam ikan.

Program Pengmas ini dilaksanakan di panti asuhan produktif yaitu panti asuhan Muhammadiyah Kenjeran Surabaya yang terletak di wilayah pesisir Surabaya. Diharapkan mitra Program Pengmas ini dapat dijadikan percontohan dan mensosialisasikan program ini lebih lanjut kepada masyarakat sekitarnya dan pembudidaya ikan lele di kota Surabaya.

Dalam pelaksanaan kegiatan Pengmas ini, secara garis besar dapat dibagi menjadi tahapan-tahapan untuk mencapai tujuan. Tahapan kegiatan adalah sebagai berikut: 


\section{Tahap Pertama}

Penyuluhan budidaya lele dumbo sistem akuaponik, hal ini dimaksudkan supaya mendapatkan wawasan dan pemahaman yang benar terkait budidaya sistem akuaponik. Pelaksanaan kegiatan ini dilaksanakan tanggal 30 Juli 2015 di ruang pertemuan Panti Asuhan Muhammadiah Kecamatan Kenjeran kota Surabaya.

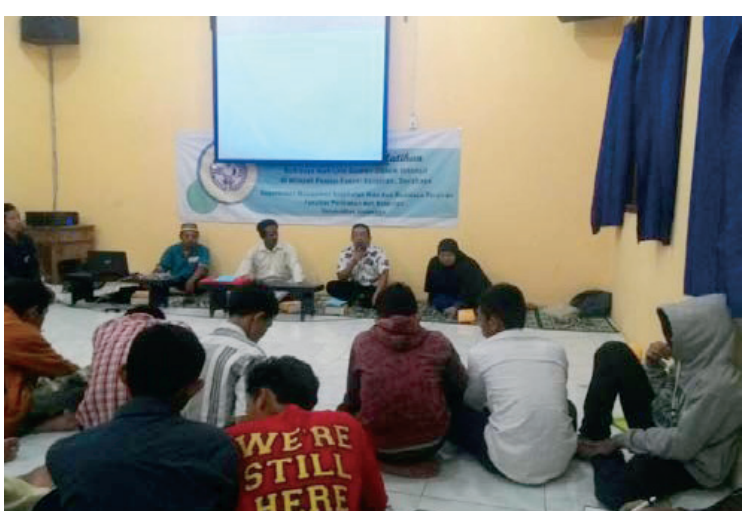

Gambar 1. Penyuluhan budidaya lele dumbo

\section{Tahap Kedua}

Pembuatan konstruksi kolam dengan budidaya lele dumbo sistem akuaponik, dimulai dari penyiapan lokasi untuk kolam, kebutuhan alat dan bahan sampai dengan cara perawatan kolam sebelum penebaran benih ikan lele. Pelaksanaan pembuatan kolam mulai dilaksanakan pada bulan Agustus 2015, dengan membangun 7 kolam di Panti Asuhan Muhammadiyah Kenjeran Surabaya.

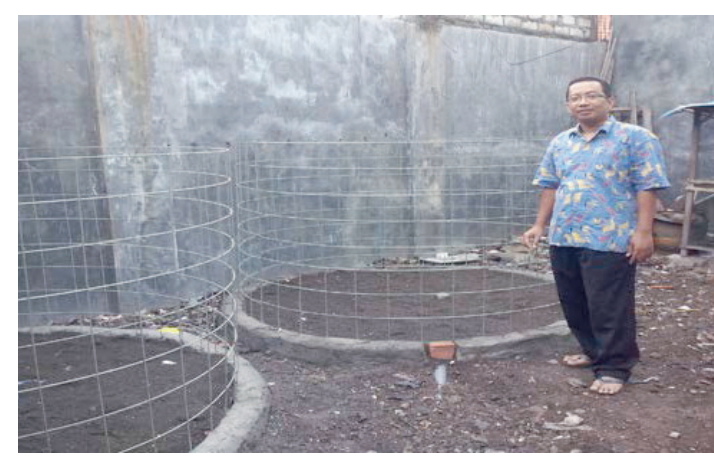

Gambar 2. Pembuatan Konstruksi Kolam

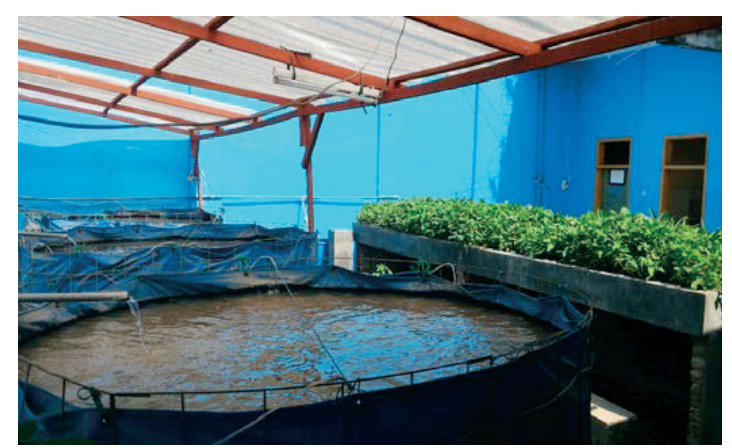

Gambar 3. Konstruksi Kolam Lele

\section{Tahap Ketiga}

Pendampingan model budidaya lele dumbo sistem akuaponik serta evaluasi dan monitoring dengan harapan didapatkan solusi dalam meningkatkan produksi. Analisa usaha sistem budidaya yang meliputi analisa produksi dan analisa usaha. Kegiatan pengmas telah menampakkan hasil,yaitu pada bulan Oktober 2015 telah mulai melakukan kegiatan panen. Hasil panen dipasarkan secara langsung di tempat yaitu dengan mempersiapkan sarana penjualan di Panti Asuhan Muhammadiyah Kenjeran Surabaya.

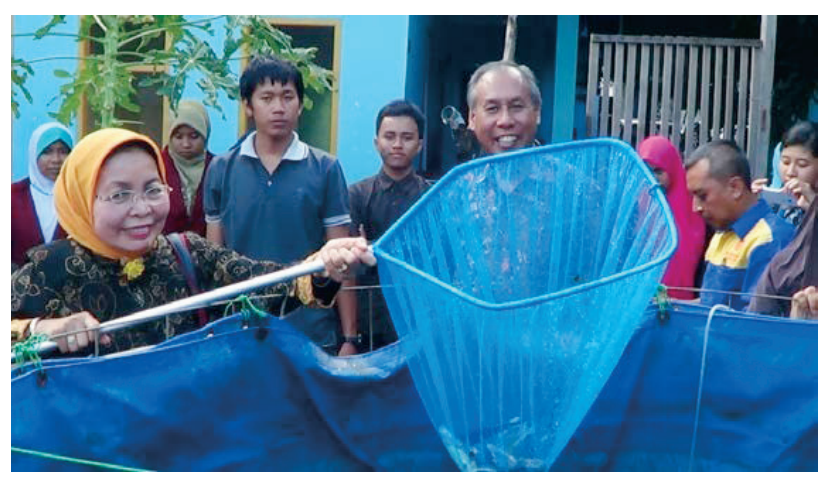

Gambar 4. Panen Lele Dumbo

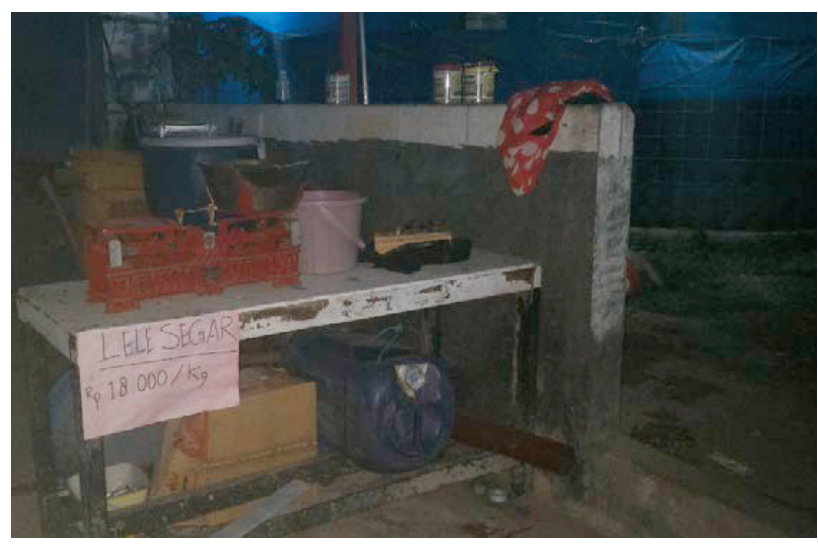

Gambar 5. Memasak Lele Dumbo

\section{SIMPULAN}

Kegiatan budidaya lele dumbo akan semakin marak apabila dikembangkan di wilayah pesisir Kota Surabaya mengingat banyaknya potensi bahan pakan murah berupa limbah ikan tanggkapan yang kurang dimanfaatkan oleh masyarakat pesisir. Hanya saja saat ini lahan dan sumber air masyarakat pesisir kota Surabaya umumnya terbatas, sehingga perlu diperkenalkan suatu model budidaya ikan lele dumbo dengan pemanfaatan lahan dan sumber air yang terbatas. Mengatasi masalah tersebut, diperlukan sistem teknologi budidaya ikan yang tepat untuk diterapkan pada kegiatan usaha budidaya ikan lele dumbo di kota Surabaya dan teknologi tersebut adalah budidaya ikan lele dumbo dengan sistem akuaponik dalam kolam terpal. 
Program Pengmas ini dilaksanakan di panti asuhan produktif yaitu panti asuhan Muhammadiyah Kenjeran Surabaya yang terletak di wilayah pesisir Surabaya. Diharapkan mitra Program Pengmas ini dapat dijadikan percontohan dan mensosialisasikan program ini lebih lanjut kepada masyarakat sekitarnya dan kelompok usaha lele lainnya.

\section{DAFTAR PUSTAKA}

Boyd, C.E. 1992. Water Quality In Ponds For Aquaculture. Bermingham PublishingCo Bermingham, Alabama.

Effendie, M.I. 1997. Biologi Perikanan. Yayasan Pustaka Nusantara, Fakultas Perikanan IPB, Bogor.
Hernowo dan Suyanto, S. 2000. Pembenihan dan Pembesaran Lele. Penebar Swadaya. Jakarta.

Lesmana, D.S. 2002. Kualitas Air untuk Ikan Hias Air Tawar. Penebar Swadaya. Jakarta.

Prihartono, K, Rasidik, J dan Arie, U. 2000. Mengatasi Permasalahan Budidaya Lele Dumbo. Penebar Swadaya. Jakarta.

Sutisna, D.H dan R. Sutarmanto. 1995. Pembenihan Ikan Air Tawar. Kanisius, Yogyakarta.

Verhoef, E dan Verhallen. 2000. The Complete Encyclopedia Of Tropical Fish. Hof and Land Typografie Maorssen, Netherlands. 404 hal.

Zonneveld, N., E.A Huisman dan J.H Boon. 1991. PrinsipPrinsip Budidaya Ikan. PT. Gramedia, Jakarta. 318 hal. 